\title{
A comparison of summer nutrient data obtained in Königshafen Bay (North Sea, German Bight) during two investigation periods: 1979-1983 and 1990-1992
}

\author{
G. Schneider \& P. Martens \\ Biologische Anstalt Helgoland, Wattenmeerstation Sylt; D-25992 List, \\ Federal Republic of Germany.
}

\begin{abstract}
A comparison of summer nutrients obtained during the investigation periods 1979-1983 and 1990-1992 was made, to elucidate whether or not changes have occurred in Königshafen Bay during the last decade. In both the flood current as well as in the ebb current, concentrations of silicate, phosphate, nitrite and nitrate have decreased. Ammonia, however, has increased by a factor of two in the flood current waters, but was similar in both investigation periods in the ebb current waters. In addition, a significant increase of salinity has been observed. The differences between flood and ebb current median nutrient concentrations suggest that the bay was a source of nutrients during the 1979-1983 period, exporting large amounts of silicate, nitrite and ammonia with the ebb current. Today, the bay appears to be more a sink than a source of nutrients. Export rates of silicate and nitrite are greatly reduced and phosphate and ammonia are imported nowadays. Nitrate fluxes were in balance during both periods. Reasons for the observed changes are discussed.
\end{abstract}

\section{INTRODUCTION}

During the last decades, intensified human activities resulted in increased inputs of nutrients into the North Sea. Therefore, elevated nutrient levels have been observed since the mid-'sixties and the early 'seventies in the open North Sea (Radach et al., 1990), as well as in the coastal Wadden Sea areas (e.g. Hickel, 1989; Martens, 1989a, b; Boddeke \& Hagel, 1991; De Jonge \& Essink, 1991; Martens, 1992). In addition, there is evidence that drastic changes of Wadden Sea biota occurred in the Netherlands coastal zone (Beukema, 1991; De Jonge et al., 1993). In the northernmost part of the German Bight, changes of bottom communities were also observed (Reise et al., 1989) which are assumed to be due, at least in part, to increased eutrophication.

The latter study was performed in Königshafen Bay, an inlet at the northern tip of the North-Frisian island of Sylt (Fig. 1). This shallow bay covers an area of $4.2 \mathrm{~km}^{2}$, the average water depth during high tide is about $1 \mathrm{~m}$ and the water volume exchanged in one tidal cycle amounts to about $4 \times 10^{6} \mathrm{~m}^{3}$ (Hartke, unpubl.). The bay is populated with different benthic biota, e.g. mussel beds, seagrass beds, sand-flats with populations of Arenicola and some others, which play the most important role in the energy flux and the cycling of organic material (Asmus \& Asmus, 1985, 1990; Reise, 1985). Nutrient concentrations were studied in the bay during the period 1979-1983. 
In 1990, a joint research programme (SWAP) started, which focusses on exchange processes between the Wadden area of Sylt and the adjacent North Sea. Within the framework of this programme, special attention was paid to Königshafen Bay during the years 1990-1992; the investigations also included nutrient determinations. These measurements offer the opportunity to compare recent nutrient levels in Königshafen Bay with those measured approximately a decade ago at the same study site. Therefore, a closer look at possible differences in nutrient concentrations on a medium-to-long time scale is possible for this small bay. However, this paper is restricted only to the summer period because most of the data were obtained during this season.

\section{MATERIALS AND METHODS}

The Königshafen studies were carried out at a station indicated by a black triangle in Figure 1, on 15 occasions during the summer months (June to August) of 1979 to 1983 , and during 24 cruises between 1990 and 1992. The station was located in a narrow but comparatively deep tidal gully (about $5 \mathrm{~m}$ at high tide) near the northeastern tip of the small island "Uthörn". A research catamaran was used for samplings every thirty minutes over half a tidal cycle, either from low tide to high tide, or vice versa. Water samples were taken from a depth of about $1 \mathrm{~m}$ using a Nansen reversing water bottle. The following nutrients were determined by means of the methods outlined in Grasshoff (1976): silicate,
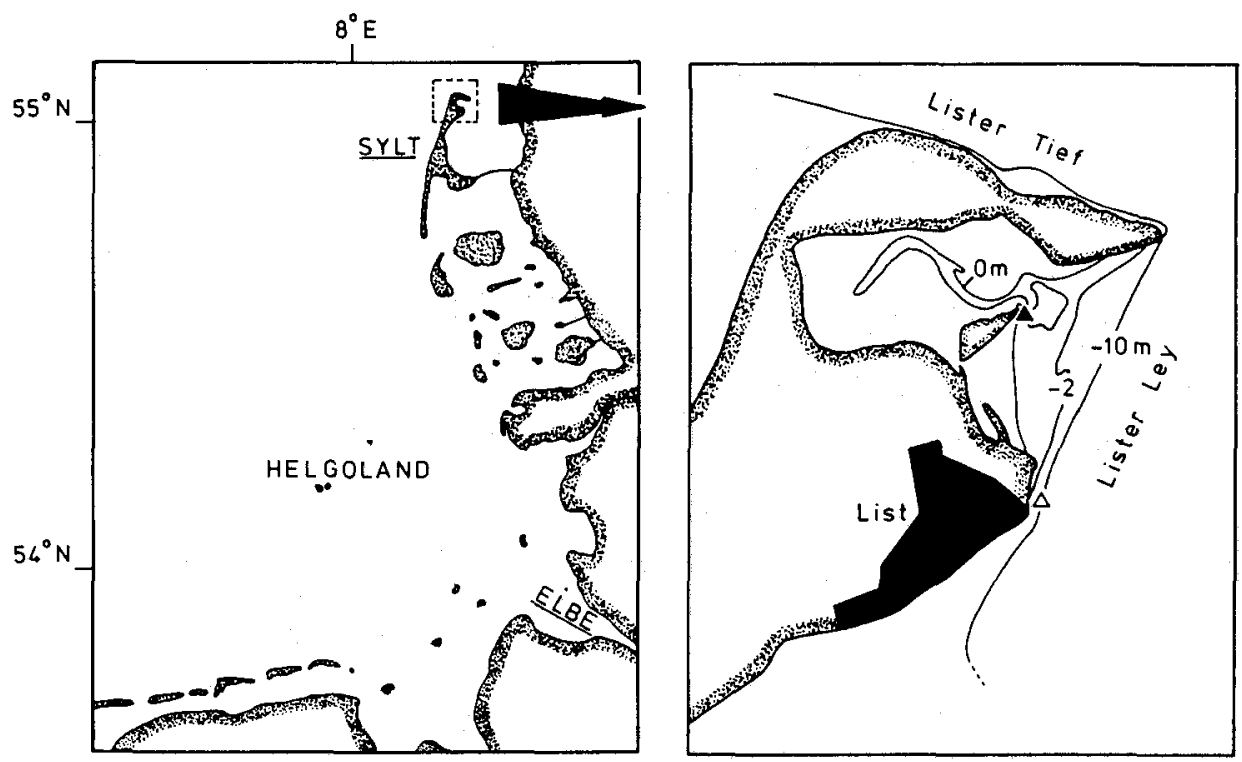

Fig. 1. Left: The German Bight (North Sea) with the North-Frisian isles at the north-eastern boundary. Sylt is the northernmost island of this archipelago. Dotted line indicates the area presented in detail on the right. Right: The northern tip of Sylt with the broad inlet called, for historical reasons, "Königshafen" ("King's harbour"). The "Lister Tief" and the "Lister Ley" are deep tidal channels connecting the wadden areas with the open North Sea. Black triangle denotes the sampling site 
phosphate, nitrate, nitrite and ammonia. Salinity values were obtained from bottle samples using an Autolab (1979-1983) and a Guildline (1990-1992) salinometer. Comparability of the data sets was insured by visits to the same station and use of the same sampling strategy and methods.

For each investigation period, the data were pooled separately for the flood and the ebb current. Since none of the data sets showed a normal distribution, the median was used, together with its $95 \%$ confidence interval, to characterize average conditions. To test for statistical differences, the median-test according to the fourfold table was carried out (Sachs, 1992).

\section{RESULTS}

Although the comparison of the data sets revealed distinct differences in the nutrient concentrations of Königshafen waters between the early 'eighties and the early 'nineties (Tables 1 and 2), there is no evidence of increased eutrophication in the area. Flood current concentrations of silicate, phosphate, nitrate and nitrite were significantly lower

Table 1. Nutrient concentrations in the flood current waters in the two investigation periods ( $\mu \mathrm{mol}$ $\left.\mathrm{1}^{-1}\right)$. Median, $95 \%$ confidence interval, total range of data, and numbers of measurements (n). Results of median test are also given. $\mathrm{P}=$ probability levels: ${ }^{*} \mathrm{p}<0.05,{ }^{*} \mathrm{p}<0.01,{ }^{* *} \mathrm{p}<0.0001$, n. $s .=$ not significant

\begin{tabular}{|c|c|c|c|c|}
\hline & $1979-1983$ & $1990-1992$ & $\mathrm{Chi}^{2}$ & $\mathrm{p}$ \\
\hline \multicolumn{5}{|c|}{ Silicate } \\
\hline Median & 7.40 & 3.09 & 27.9 & $\cdots$ \\
\hline $95 \%$ C. I. & $7.00-10.00$ & $2.59-3.46$ & & \\
\hline Range & $1.40-24.50$ & $0.85-11.25$ & & \\
\hline $\mathrm{n}$ & 60 & 140 & & \\
\hline \multicolumn{5}{|c|}{ Phosphate } \\
\hline Median & 1.90 & 1.25 & 48.0 & $\cdots$ \\
\hline $95 \%$ C. I. & $1.65-2.40$ & $1.13-1.37$ & & \\
\hline Range & $0.64-4.20$ & $0.05-5.25$ & & \\
\hline n & 104 & 163 & & \\
\hline \multicolumn{5}{|c|}{ Nitrate } \\
\hline Median & 1.45 & 0.73 & 21.4 & $\cdots$ \\
\hline $95 \%$ C. I. & $1.22-1.66$ & $0.57-0.74$ & & \\
\hline Range & $0.15-4.40$ & $\begin{array}{ll}0 & -4.83\end{array}$ & & \\
\hline $\mathrm{n}$ & 75 & 166 & & \\
\hline \multicolumn{5}{|c|}{ Nitrite } \\
\hline Median & 0.29 & 0.26 & 4.83 & - \\
\hline $95 \%$ C. I. & $0.26-0.32$ & $0.24-0.30$ & & \\
\hline Range & $0.14-0.67$ & $0.01-0.67$ & & \\
\hline$n$ & 73 & 179 & & \\
\hline \multicolumn{5}{|c|}{ Ammonia } \\
\hline Median & 1.14 & 2.64 & 32.1 & ..* \\
\hline $95 \%$ C. I. & $0.95-1.45$ & $2.43-2.85$ & & \\
\hline Range & $0.10-4.20$ & $0.45-8.53$ & & \\
\hline n & 98 & 136 & & \\
\hline
\end{tabular}


Table 2. Nutrient concentrations in the ebb current waters in the two investigation periods ( $\left.\mu \mathrm{mol} 1^{-1}\right)$.

Abbreviations as in Table 1

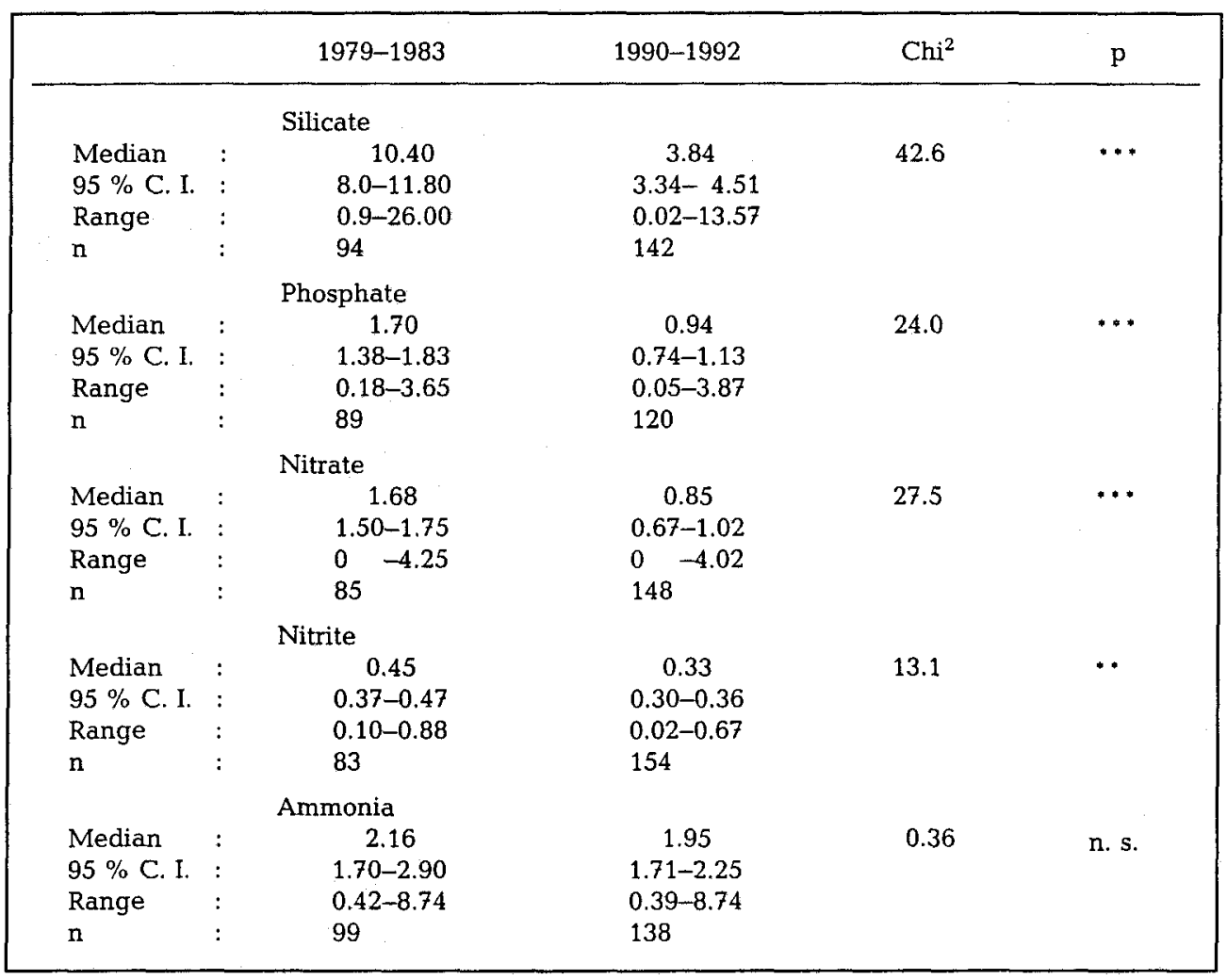

between 1990 and 1992, when compared with the 1979-1983 data set (Fig. 2), and only ammonia has increased by a factor exceeding two. Similar results were obtained for the ebb current, with lower concentrations of nutrients in the 1990-1992 period than that of 1979-1983. An exception is ammonia, which showed no significant difference between the two investigation periods. Additionally, a significant increase of salinity by about 2 $\left(\mathrm{Chi}^{2}=237, \mathrm{p}<0.0001\right)$ was observed (Fig. 3). Median salinities were 29.61 in the 1979-1983 period, but 31.75 in the early 'nineties, without any difference between the ebb and the flood currents.

The observed changes in nutrient concentrations also indicate a change of nutrient net-transport directions between Königshafen and the adjacent Lister Ley. Ebb current concentrations of silicate, nitrite, and ammonia were higher than flood current values in the 1979-1983 period - thus indicating a net-export of these nutrients from Königshafen to the Lister Ley (Table 3, Fig. 4). Phosphate and nitrate fluxes were in balance. In the early 'nineties, silicate as well as nitrite was still exported, however, at considerably reduced rates. Nitrate fluxes were in balance, as in the first investigation period. However, phosphate and ammonia were taken up by Königshafen, since the flood current values of these nutrients were higher than the ebb current concentrations. These 

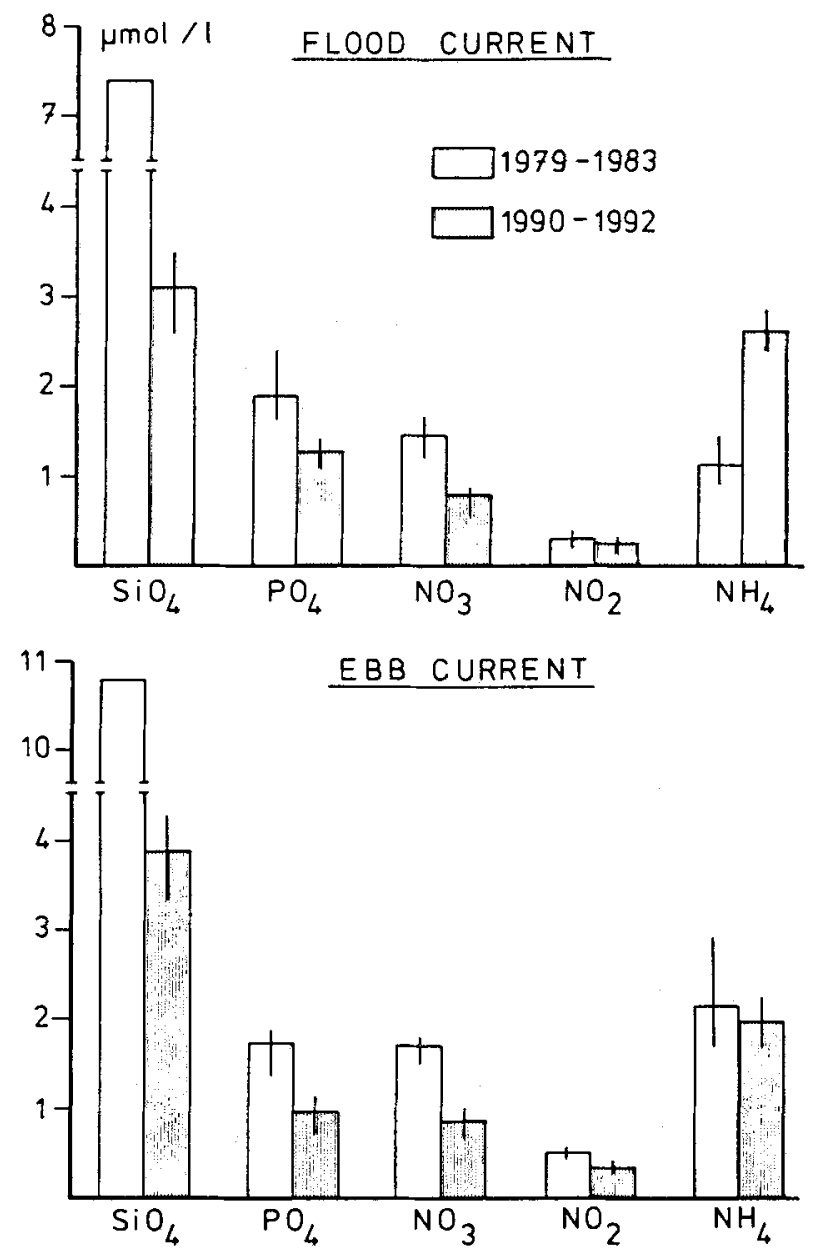

Fig. 2. Median values of nutrient concentrations in the flood and in the ebb current water masses during 1979-1983 and 1990-1992. Vertical bars show $95 \%$ confidence intervals. For silicate these intervals are not shown for the 1979 to 1983 period, for technical reasons. Values are: $7.0-10.0$ in the flood current, and $8.0-11.8$ in the ebb current waters

findings suggest that the Königshafen ecosystem has become more retentive concerning nutrients imported with the flood current waters. Today, the bay appears to be predominately a sink for nutrients, whereas the opposite was true for the period 1979-1983.

\section{DISCUSSION}

Although there are general trends of rising concentrations of nutrients in the North Sea, at the particular location of Königshafen Bay just the opposite was observed. This unexpected pattern is difficult to explain, since it is not clear whether or not these changes are restricted only to Königshafen Bay or may have been occurring over a larger 


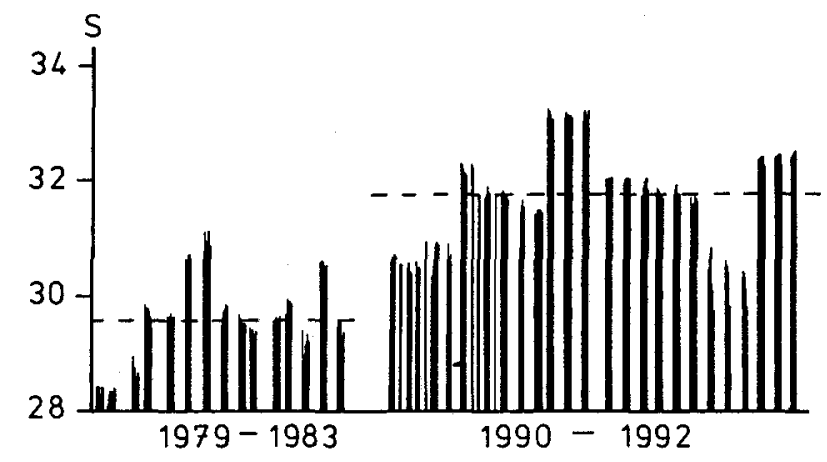

Fig. 3. Data of salinity obtained in the two investigation periods. Dotted lines indicate median values

Table 3. Comparison of flood and ebb current nutrient concentrations (median values, $\mu \mathrm{mol} \mathrm{1}^{-1}$ ) within the investigation periods studied, and results of median test for tidal differences. $\mathrm{P}=$ probability level, " $\mathrm{p}<0.05, \cdots p<0.01, \cdots p<0.001, n . s .=$ not significant. For ranges, $95 \%$ confidence intervals and number of data see Tables 1 and 2. " $\mathrm{D}$ " gives the difference between flood current median minus ebb current median. Negative values indicate a net export from Königshafen with the ebb current, positive values indicate a net import to Königshafen with the flood current

\begin{tabular}{|c|c|c|c|c|c|}
\hline & Flood current & Ebb current & $\mathrm{Chi}^{2}$ & $\mathrm{p}$ & $\mathrm{D}$ \\
\hline \multicolumn{6}{|c|}{ 1979-1983 } \\
\hline Silicate & 7.40 & 10.40 & 5.93 & $*$ & -3.00 \\
\hline Phosphate & 1.90 & 1.70 & 0.86 & n. s. & \pm 0 \\
\hline Nitrate & 1.45 & 1.68 & 1.47 & n. s. & \pm 0 \\
\hline Nitrite & 0.29 & 0.45 & 14.2 & $\cdots$ & -0.16 \\
\hline Ammonia & 1.14 & 2.16 & 11.2 & $\cdots *$ & -1.02 \\
\hline \multicolumn{6}{|c|}{$1990-1992$} \\
\hline Silicate & 3.09 & 3.84 & 5.11 & $*$ & -0.75 \\
\hline Phosphate & 1.25 & 0.94 & 9.43 & $*$ & +0.31 \\
\hline Nitrate & 0.73 & 0.85 & 2.86 & n. s. & \pm 0 \\
\hline Nitrite & 0.26 & 0.33 & 11.5 & $\cdots$ & -0.07 \\
\hline Ammonia & 2.64 & 1.95 & 13.1 & $\cdots$ & +0.69 \\
\hline
\end{tabular}

area. Nevertheless, we assume that the changes in the flood current nutrient concentrations and in salinity are due to a reduced influence of River Elbe waters in the region here mentioned. Hickel (1980) was able to show that variations of Elbe freshwater discharge volumes has a marked effect on the salinity in the Sylt area, due to differences in the northward transport of the water masses. Therefore, it is clear that varying amounts of nutrients associated with these polluted waters will be advected to our area. Recently, Gaumert (1991) showed that Elbe River discharge volumes declined throughout the 1980s, and, since the nutrient concentrations in the Elbe waters did not change drastically, nutrient inputs to the North Sea were lower at the end of the 'eighties than at the beginning of that decade. Therefore, it can be assumed that this led to a much smaller 


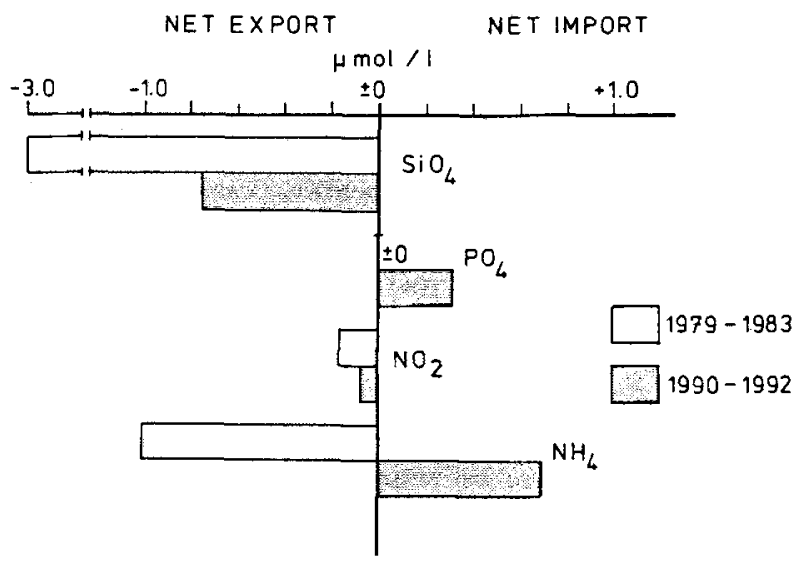

Fig. 4. Difference of nutrient flood current median values minus ebb current median values. Negative values indicate net export, positive values net import. Nitrate is not not shown because differences were \pm 0 in both periods

transport of nutrients and freshwater to the Sylt region, resulting in lower nutrient concentrations and higher salinities in the study area.

In addition, data from the weather station in List indicate a decrease of local rain between 1979 and 1992, leading to a reduced input of nutrients to the sea around the island of Sylt by direct precipitation and run-off from land.

However, both arguments must remain speculative and cannot, for example, explain the increase of ammonia in the flood current waters. Therefore, we have to face the problem that we cannot give a fully satisfactory explanation for the changes observed, due to a lack of sufficient data from other localities in the Sylt region during the 1979-1983 period.

Dealing with the ebb current values, it was found that, in both investigation periods, the concentrations of silicate, nitrate and ammonia differed significantly from that in the flood current. For the 1990-1992 period, this was also the case for phosphate. This means that the water masses circulating through Königshafen Bay within a tidal cycle will be depleted or enriched in the above mentioned nutrients by organism action and/or exchange processes with the sea bed. The general fact that benthic communities influence the nutrient load of the water masses passing over that community was demonstrated by the tunnel and flume techniques (e.g. Dame \& Dankers, 1988; Prins \& Smaal, 1990; Dame et al., 1991) and by investigating pore water nutrient profiles in the sediment (e.g. Hüttel, 1990). Experiments carried out on a Königshafen mussel bed, with the tunnel and flume technique (Asmus et al., 1992) revealed an enrichment of the flowing water with ammonia and phosphate during passage through the system. Since the tunnel and the flume were 10 and $20 \mathrm{~m}$ long, respectively, and current velocities ranged from 1 to $12 \mathrm{~cm} \mathrm{~s}^{-1}$, a water residence time between 2 and 30 minutes over the mussel bed is enough to induce measurable changes in the nutrient content. Recent experiments on sand flats with and without Arenicola showed that, during calm weather, the lugworm-inhabited sediment released many more nutrients than the control without 
worms. During rough weather, however, release was similar in both compartments, pointing to the additional role of external energy (wind in this case) for nutrient release due to wave-induced sediment resuspension. By contrast, results obtained from areas covered with seagrass (Asmus et al., 1994) showed the opposite situation, i.e. the uptake of nutrients with an associated depletion of waters passing over that community.

We therefore suppose that the nutrient concentrations in the ebb current depend upon the concentrations in the flood current, and the superimposing changes, due to organism action during the passage through Königshafen Bay. The increased uptake of nutrients in the early 'nineties as indicated by the " $\mathrm{D}$ " values in Table 3 (see also Fig. 4) could be due to fundamental changes in the Königshafen community structure - with more efficient nutrient retention mechanisms now prevailing. This may be achieved by a relative decline of heterotrophic compartments and/or the relative increase of autotrophs. Assuming a higher plant biomass in recent years, as compared with the 1979-1983 period, the increased formation of plant tissues acts as a temporary sink for nutrients, which, therefore, takes no part in short-term regeneration cycles.

It is, indeed, known that the Königshafen Bay communities are now rather different from those in the early 'eighties, due to winter conditions prior to the summers sampled. According to the data from the Deutscher Wetterdienst during the 1979-1983 period, three winters had rather low temperatures and only one was unusually mild. By contrast, 1990 and 1992 had the warmest winters of all the years investigated. More important than temperature alone - during the severe winter of 1979 there was heavy ice-cover and drift which destroyed the Königshafen mussel beds and much of the larger algae and the seagrass, but left, for example, the sand-flats with Arenicola comparatively undamaged (Asmus, pers. comm.). Ice was also observed in the winters of 1980 and 1982, but it had a less destructive effect. Since the damaged and almost entirely absent communities recovered only gradually in the following years, most summer data in the 1979-1983 period were obtained from a disturbed ecosystem in which some key biota were absent or only poorly-developed. At that time, the autotrophic compartment was greatly reduced. Large amounts of nutrients were probably released by the burrowing action of Arenicola, but also due to physical forces (e.g. wave action) because few plants, and no mussel beds, protected the sediments and reduced wave-forces.

Today, the mussel beds are well-developed and are densely covered with Fucus which acts as a trap for nutrients released by the mussels. According to Asmus (pers. comm.), large algae as well as seagrass are much more abundant now than in 1979 and 1980. In addition, green algal mats have become abundant during the last decade (Reise, 1983). Below dense algal mats, the sediment becomes anoxic and nutrients coming out due to this condition fulfil the nutritional demands of the algae. However, the initial phase of mat formation and the build-up of a large part of total biomass, which can reach $300-500 \mathrm{~g}$ organic substance per $\mathrm{m}^{2}$ (Reise et al., unpubl.), can be expected to depend upon the nutrients dissolved in the flood current waters entering Königshafen Bay, since the sediment is not anoxic at that time. Therefore, an increase of these mats also leads to a depletion of nutrients - most of which are not recycled within a short time.

Although we have insufficient data for definite proof, there is evidence that the concentrations of nutrients will be considerably affected by the various benthic communities as proposed above. Consequently, whether Königshafen Bay acts as a source or a sink for nutrients depends upon the ratio between the autotrophic and heterotrophic 
compartments. However, this ratio is subject to disturbances, e.g. due to cold winters with ice, unusually warm winters (Beukema, 1992) or heavy storms (Nehls \& Thiel, 1993), and the role of Königshafen Bay might change in time, and may oscillate between the extremes of natural variability.

Acknowledgements. Part of this study was supported by the Federal Ministry for Research and Technology. This is publication no. 130 of the project "Ecosystem Research Wadden Sea". We thank the crew of RV "Mya", N. Kruse and P. Elvert, for their patience when moored at the study site. We are grateful for the skilful help of our assistant of long standing, C. Reineke, and the contribution of I. Bock in analysing the 1992 samples. The "Deutscher Wetterdienst" supported this work with meteorological data. Additional thanks are due to all who contributed to this paper through personal communications and constructive criticism. Thanks also to A. Starke who kindly revised the English, and to two unknown reviewers who made valuable comments to a first version of this paper.

\section{LITERATURE CITED}

Asmus, H. \& Asmus, R. M., 1985. The importance of grazing food chain for energy flow and production in three intertidal sand bottom communities of the northern Wadden Sea. - Helgoländer Meeresunters. 39, 273-301.

Asmus, H. \& Asmus, R. M., 1990. Trophic relationships in tidal flat areas: To what extent are tidal flats dependent on imported food? - Neth. J. Sea Res. 27, 93-99.

Asmus, H., Asmus, R. M., Prins, T. C., Dankers, N., Francés, G., Maaß, B. \& Reise, K., 1992. Benthicpelagic flux rates on mussel beds: Tunnel and tidal flume methodology compared. - Helgoländer Meeresunters. 46, 341-361.

Asmus, H., Asmus, R. M., Wille, A., Francés-Zubillaga, G. \& Reise, K., 1994. Complementary oxygen and nutrient flux in sea-grass beds and mussel banks? In: Changes in fluxes in estuaries: implications from science to management. Ed. by K. R. Dyers. Olsen \& Olsen, Fredensborg. (In press.)

Beukema, J. J., 1991. Changes in composition of bottom fauna of a tidal-flat area during a period of eutrophication. - Mar. Biol. 111, 293-301.

Beukema, J. J., 1992. Expected changes in the Wadden Sea benthos in a warmer world: lessons from periods with mild winters. - Neth. J. Sea Res. 30, 73-79.

Boddeke, R. \& Hagel, P., 1991. Eutrophication on the North Sea continental zone, a blessing in disguise. - C.M./ICES, E7, 1-18.

Dame, R. F. \& Dankers, N., 1988. Uptake and release of materials by a Wadden Sea mussel bed. J. exp. mar. Biol. Ecol. 118, 207-216.

Dame, R. F., Dankers, N., Prins, T., Jongsma, H. \& Smaal, A., 1991. The influence of mussel beds on nutrients in the Western Wadden Sea and Eastern Scheldt estuaries. - Estuaries 14, 130-138.

Gaumert, T., 1991. Trend-Entwicklung der Nährstoffe im Elbwasser von 1980 bis 1989. ARGE Elbe, Hannover, $23 \mathrm{pp}$.

Grasshoff, K. (Ed.), 1976. Methods of seawater analysis. Verl. Chemie, Weinheim, $317 \mathrm{pp}$.

Hickel, W., 1980. The influence of Elbe river water on the Wadden Sea of Sylt (German Bight, North Sea). - Dt. hydrogr. Z. 33, 43-52.

Hickel, W., 1989. Inorganic micronutrients and the eutrophication in the Wadden Sea of Sylt (German Bight, North Sea). In: Proceedings of the twenty-first European Marine Biology Symposium, Gdansk, 14.-19. 9. 1986. Ed. by R. Z. Klekowski, E. Styczyńska-Jurewicz \& L. Falkowski. Polish Academy of Sciences, Wrocław, 309-318.

Hüttel, M., 1990. Influence of the lugworm Arenicola marina on porewater nutrient profiles of sand flat sediments. - Mar. Ecol. Prog. Ser. 62, 241-248.

Jonge, V. N. de \& Essink, K., 1991. Long-term changes in nutrient loads and primary and secondary production in the Dutch Wadden Sea. In: Estuaries and coasts: spatial and temporal intercomparisons. Ed. by M. Elliot \& J.-P. Ducrotoy. Olsen \& Olsen, Fredensborg, pp. 307-316.

Jonge, V. N. de, Essink, K. \& Boddeke, R., 1993. The Dutch Wadden Sea: a changed ecosystem. Hydrobiologia 265, 45-71. 
Martens, P., 1989a. Inorganic phytoplankton nutrients in the Wadden Sea areas off SchleswigHolstein. I. Dissolved inorganic nitrogen. - Helgoländer Meeresunters. 43, 77-85.

Martens, P., 1989b. On trends in nutrient concentration in the northern Wadden Sea of Sylt. Helgoländer Meeresunters. 43, 489-499.

Martens, P., 1992. Inorganic phytoplankton nutrients in the Wadden Sea areas off SchleswigHolstein. Il. Dissolved ortho-phosphate and reactive silicate with comments on the zooplankton. - Helgoländer Meeresunters. 46, 103-115.

Nehls, G. \& Thiel, M., 1993. Large-scale distribution patterns of the mussel Mytilus edulis in the Wadden Sea of Schleswig-Holstein: Do storms structure the ecosystem? - Neth. J. Sea Res. 31, 181-187.

Prins, T. C. \& Smaal, A. C., 1990. Benthic-pelagic coupling: the release of inorganic nutrients by an intertidal bed of Mytilus edulis. In: Trophic relationships in the marine environment. Ed. by M. Barnes \& R. N. Gibson. Univ. Press, Aberdeen, 89-103.

Radach, G., Berg, J. \& Hagmeier, E., 1990. Long-term changes of the annual cycles of meteorological, hydrographic, nutrient and phytoplankton time series at Helgoland and LV Elbe 1 in the German Bight. - Cont. Shelf Res. 10, 305-328.

Reise, K., 1983. Sewage, green algal mats anchored by lugworms, and the effects on Turbellaria and small Polychaeta. - Helgoländer Meeresunters. 36, 151-162.

Reise, K., 1985. Tidal flat ecology. Springer, Heidelberg, $191 \mathrm{pp}$.

Reise, K., Herre, E. \& Sturm, M., 1989. Historical changes in the benthos of the Wadden Sea around the island of Sylt in the North Sea. - Helgoländer Meeresunters. 43, 417-433.

Sachs, L., 1992. Angewandte Statistik. Springer, Heidelberg, 846 pp. 